\title{
Keefektifan Model Pembelajaran Make A Match Berbantu Media Panteru (Papan Tempel Seru) Terhadap Hasil Belajar Kognitif Siswa Pada Pembelajaran Tema 6 Subtema 1
}

\author{
Nahdiana Rizqi Aulia ${ }^{1 *}$, Sri Suneki ${ }^{2}$, Veryliana Purnamasari ${ }^{3}$ \\ 123Jurusan Pendidikan Guru Sekolah Dasar, Fakultas Ilmu Pendidikan Universitas PGRI Semarang, Indonesia
}

\author{
A R T I CLE I NFO \\ Article history: \\ Received 18 May 2019 \\ Received in revised form \\ 30 June 2019 \\ Accepted 15 July 2019 \\ Available online 25 August \\ 2019 \\ Kata Kunci: \\ : Model Make A Match \\ media Panteru, dan hasil \\ belajar kognitif. \\ Keywords: \\ Make A Match Model, \\ Panteru media, and \\ cognitive learning outcomes
}

\begin{abstract}
A B S T R A K
Latar belakang penelitian ini adalah rendahnya nilai kognitif siswa pada pembelajaran Tema 6 Subtema 1 tentang cita-citaku, aku dan cita-citaku, hal tesebut di buktikan dengan kurang efektifnya pembelajaran sebelumnya oleh peserta didik. Hasil Pretest menunjukkan bahwa presentase klasikal pretest $70 \%$ sedangkan pada presentase klasikal posttest $100 \%$. Serta berdasarkan hasil uji $t$ diketahui $t_{\text {hitung }}$ lebih dari $t_{\text {tabel }}$ 8,063>1,753. Kesimpulan bahwa Penerapan model Make A Match Berbantu Media Panteru Terhadap Hasil Belajar Kognitif Pada Pembelajaran Tema 6 Subtema 1 Kelas IV SDN Pujut 01 Batang. Hasil rata-rata nilai Pretest menunjukkan bahwa dari 16 peserta didik hanya 5 peserta didik yang dinyatakan lulus KKM diatas 70, dan 11 peserta didik dinyatakan tidak lulus KKM di bawah 70 . Setelh diberikan perlakuan peserta didik mendapat nilai di atas KKM 70 , dan dari hasil posttest dari 16 peserta didik ada 14 peserta didik yang dinyatakan lulus KKM yang mendapatkan nilai tuntas diatas KKM 70. Dan dari pengujian ketuntasan belajar klasikal hasil belajar peserta didik secara keseluruhan mencapai presentase belajar klasikal lebih dari $70 \%$ yaitu $88 \%$. Berdasarkan hasil penelitian yang dilakukan saran yang dapat disampaikan adalah agar Model Make A Match berbantu media Panteru dapat digunakan sebagai satu alternatif guru dalam mengajar.
\end{abstract}

\section{A B S T R A C T}

The background of this study is the low cognitive value of students in Theme 6 Subtheme 1 learning about my ideals, me and my ideals, this is proven by the ineffectiveness of previous learning by students. Pretest results showed that the percentage of classical pretest is $70 \%$ while the classical percentage of posttest is $100 \%$. Based on the results of the t test, it was known that tcount was more than ttable 8.063> 1.753. The conclusion that the application of the Make A Match model helped Panteru Media Against Cognitive Learning Outcomes in Learning Theme 6 Subtheme 1 Class IV SDN Pujut 01 Batang. The results of the average Pretest value indicate that in 16 students only 5 students who were declared to have passed the KKM above 70, and 11 students were declared not to have passed the KKM below 70. After giving the treatment the students got above 70, and from the results posttest of 16 students there were 14 students who passed the KKM which got a complete score above KKM 70. And from the classical learning completeness test the overall learning outcomes of students reached a percentage of classical learning more than $70 \%$ ie $88 \%$.Based on the results of research, it can be conducted that the Make A Match Model with the help of Panteru media can be used as an alternative teacher in teaching.

\footnotetext{
${ }^{1}$ Corresponding author.

E-mail addresses: nahdiana01@Gmail.com (Nahdiana Rizqi Aulia)
} 


\section{Pendahuluan}

Pendidikan merupakan suatu upaya yang di arahkan pada kemaslahatan dan kesejahteraan pendidikan peserta didik dan masyarakat sudah berlangsung sejak dahulu kala dan tidak akan diragukan lagi ke eksistensiannya. Pendidikan telah di mulai dan dilaksanakan sejak manusia lahir ke muka bumi dalam bentuk permanen dari pemberian warisan orang tua dalam mempersiapkan anak-anaknya dalam menghadapi kehidupan di masa yang akan datang untuk mengatasi berbagai masalah yang akan datang di masa depan nanti.

Pendidikan adalah hal terpenting bagi setiap negara untuk dapat berkembang pesat. Negara yang hebat akan menempatkan pendidikan sebagai prioritas pertamanya, karena dengan pendidikan, kemiskinan pada rakyat di negara tersebut akan dapat tergantikan menjadi kesejahteraan. Bagaimanapun, dalam perkembangannya, pendidikan di Indonesia senantiasa harus menghadapi beberapa masalah di setiap tahapnya. Masalahmasalah tersebut hanya dapat diselesaikan dengan partisipasi dari semua pihak yang terkait di dalam sistem pendidikan, seperti orangtua, guru-guru, kepala sekolah, masyarakat, dan juga peserta didik itu sendiri. Pada fase input, orangtua memiliki kontribusi besar dalam memperkenalkan nilai-nilai baik kepada anak-anak mereka. Orangtua bertanggung jawab penuh untuk mendidik anak-anak mereka dengan nilai-nilai kepemimpinan, sehingga mereka mempunyai bekal yang cukup untuk menjadi cikal bakal pemimpin ketika mereka mulai memasuki institusi formal, seperti sekolah. Pada fase proses, orangtua bekerjasama dengan para guru dan kepala sekolah untuk memberikan penguatan kepada peserta didik dalam menerapkan nilai-nilai kepempinan yang baik melalui budaya organisasi di sekolah. Terakhir, pada tahap output, peserta didik harus menghadapi begitu banyak tantangan di dunia nyata, di luar sekolah. Peserta didik yang sudah melalui tahap-tahap sebelumnya di sekolah dengan budaya organisasi yang mengajarkan dan membiasakan nilai-nilai baik dalam hidupnya, maka akan tumbuh menjadi pemimpin yang hebat untuk negara ini .

Permasalahan demi permasalahan pendidikan di Indonesia dituai tiap tahunnya. Permasalahan pun muncul mulai dari aras input, proses, sampai output. Ketiga aras ini sejatinya saling terkait satu sama lain. Input mempengaruhi keberlanjutan dalam proses pembelajaran. Proses pembelajaran pun turut mempengaruhi hasil output. Seterusnya, output akan kembali berlanjut ke input dalam jenjang pendidikan yang lebih tinggi lagi atau masuk ke dalam dunia kerja, dimana teori mulai dipraktekkan. (Megawati, 2012).

Pendidikan dan pengajaran adalah salah satu usaha yang bersifat sadar tujuan yang dengan sistematis terarah pada perubahan tingkah laku menuju kedewasaan anak didik. Perubahanperubahan itu menunjukkan suatu proses yang harus dilalui. Perubahan tidak hanya berkaitan dengan penambahan ilmu pengetahuan, tetapi juga berbentuk kecakapan, keterampilan, sikap, pengertian, harga diri, minat, watak, dan penyesuaian diri (Sardiman, 2009). Menurut Djamarah dan Zain (2010) bahwa proses belajar mengajar adalah suatu proses yang sengaja diciptakan untuk kepentingan anak didik. Agar anak didik senang dan bergairah belajar, guru berusaha menyediakan lingkungan belajar yang kondusif dengan memanfaatkan semua potensi kelas yang ada. Di dalam kegiatan belajar mengajar guru tidak harus terpaku dengan menggunakan satu metode, tetapi guru sebaiknya menggunakan metode yang bervariasi agar jalannya pembelajaran tidak membosankan tetapi menarik perhatian anak didik.

Pada intinya belajar adalah ingin mendapatkan pengetahuan, keterampilan, dan pemahaman sikap mental, serta nilai-nilai (Sardiman, 2009). Dalam proses pembelajaran, guru sebagai fasilitator atau motivator memegang peranan penting dalam proses belajar mengajar. Guru harus bisa menciptakan kondisi yang dinamis dan mampu meningkatkan kualitas pembelajaran, untuk itu guru harus memilih salah satu model-model pembelajaran yang bisa meningkatkan semangat siswa untuk belajar agar siswa tidak merasa bosan berada didalam kelas. Dalam kelas metode mengajar tidak digunakan sendiri-sendiri tetapi merupakan kombinasi dari beberapa metode mengajar (Sudjana,2012) (Wandy, 2017).

Standar proses untuk satuan pendidikan dasar dan menengah merupakan salah satu standar yang dikembangkan sejak tahun 2006 oleh Badan Standar Nasional Pendidikan dan pada tahun 2007 dan diterbitkan menjadi Peraturan Menteri Pendidikan Nasional Republik Indonesia, yaitu Permendiknas RI Nomor 41 tahun 2007. Seiring dengan penyempurnaan kurikulum tingkat satuan pendidikan menjadi kurikulum 2013, maka standar proses satuan pendidikan dasar dan menengah juga mengalami penyempurnaan yang dituangkan dalam Peraturan Menteri Pendidikan dan Kebudayaan Republik Indonesia Nomor 65 Tahun 2013 tentang Standar Proses Pendidikan Dasar dan Menengah.

Dalam rangka pembaharuan sistem pendidikan nasional telah ditetapkan visi,misi, dan strategi pembangunan pendidikan nasional. Visi pendidikan nasional adalah terwujudnya sistem pendidikan sebagai pranata sosial yang kuat dan berwibawa untuk memberdayakan semua warga negara Indonesia berkembang menjadi manusia yang berkualitas sehingga mampu dan proaktif menjawab tantangan zaman yang selalu berubah. 
Mengingat kebhinekaan budaya ,keragaman latar belakang dan karakteristik peserta didik, serta tuntutan untuk menghasilkan lulusan yang bermutu, proses pembelajaran untuk setiap mata pelajaran pendidikan dasar dan menengah harus interaktif, inspiratif, menyenangkan dan memotivasi peserta didik untuk berpartisipasi aktif, serta memberikan rungan yang cukup bagi prakarsa, kreativitas dan kemandirian sesuai dengan bakat, minat perkembangan fisik serta psikologis peserta didik.

Pendidikan saat ini dijadikan modal utama untuk menyiapkan pribadi dan sumber daya manusia yang semakin maju menjadi lebih baik dengan adanya pendidikan akan menciptakan manusia yang cerdas dan kompeten. Pendidikan saat ini dianggap sebagai kebutuhan yang sangat penting dalam berlangsungnya kehidupan. Seperti yang tercantum dalam UU No. 20 Tahun 2003 tentang sistem pendidikan nasional. Yang berbunyi.

"Pendidikan berfungsi mengembangkan kemampuan dan membentuk watak serta peradaban bangsa yang bermartabat dalam rangka mencerdaskan kehidupan bangsa, bertujuan untuk berkembangnya potensi siswa agar menjadi manusia yang beriman dan bertakwa kepada Tuhan Yang Maha Esa, berakhlak mulia, sehat, berilmu, cakap, kreatif, mandiri, dan menjadi warga negara yang demokratis serta bertanggung jawab" (Bab II Pasal 3).

Pembelajaran tematik dalam kurikulum 2013 harus didesain lebih menarik dan sedekat mungkin dengan lingkungan siswa agar tercipta suasana yang menyenangkan sehingga dapat membangkitkan semangat siswa dalam menggali informasi dari materi yang akan dipelajari. Pembelajaran dirancang sedemikian rupa agar siswa dpat menentukan konsep sendiri berdasarkan pengetahuan awal sehingga akan lebih bermakna. Hal ini di dukung oleh pendapat dari Trianto (2011:26) yang menjelaskan bahwa proses pembelajaran yang aktif, kreatif, inovatif, efektif, dan menyenangkan dapat dilakukan oleh siswa yang disiapkan oleh pendidik melalui kegiatan-kegiatan yang menarik, menyenangkan untuk membangkitkan rasa ingin tahun, memotivasi siswa untuk berfikir, kritis, dan menemukan hal-hal baru.

Sesuai observasi awal yang saya lakukan tentang pembelajaran yang dilaksanakan oleh guru dalam mata pelajaran TEMATIK, saya mendapatkan hasil wawancara dari wali kelas IV SDN Pujut 01 kabupaten Batang, berdasarkan hasil wawancara saya dengan guru kelas IV yaitu ibu Rohyati S.Pd sebagai berikut : bahwa hasil belajar siswa rata-rata ada yang maksimal ada juga yang kurang maksimal,dengan sistem yang diajarkan karena mungkin anak ada yang berminat dan ada yang kurang berminat, hasil nilai siswa yang kurang memuaskan menjadi faktor terhadap pembelajaran, karena mungkin model yang digunakan masih belum moderen ,proses pembelajaran tema 6 "cita-citaku" subtema 1 "aku dan cita-citaku" dapat disimpulkan bahwa siswa kurang aktif dan tertarik terhadap materi yang disampaikan oleh guru,apakah hasil yang kurang memuaskan,apakah model yang digunakan guru belum menarik peserta didik, karena guru masih menggunakan model pembelajaran yang berpusat pada guru saja (ceramah). Hal itu di buktikan dengan siswa hanya mendengarkan. Dan akibatnya dalah rata-rata hasil belajar tema 6 "citacitaku" sub tema 1 "aku dan cita-citaku". Di dalam pembelajaran tematik terdapat tiga mata pelajaran, di salah satu mata pelajaran IPA rata-rata dari seluruh nilai siswa yaitu 68,5 dan lebih dari 45\% dari 16 siswa belum mencapai KKM yaitu 70,00.

Tersebut dapat disimpulkan bahwa dengan menggunakan solusi yang dapat digunakan untuk mengatasi masalah yang di hadapi guru dan siswa kita dapat mengembangkan model pembelajaran yang dapat menciptakan suasana belajar yang aktif menyenangkan, membantu siswa memahami materi, pelajaran yang sulit dan membantu guru mengajarkan materi yang lebih menarik lagi. Dengan mencoba model pembelajaran Make A Match, dengan penerapan model pembelajaran ini siswa akan tertarik dengan cara pembelajaran ini dimulai dengan teknik cari pasangan yaitu siswa disuruh untuk mencri pasangan kartu yang merupakan jawaban atau soal sebelum batas waktu yang di tentukan. Siswa dapat mencocokan sebelum batas waktu yang di tentukan maka siswa akan mendapatkan nilai atau poin. Pembelajaran kooperatif ini dikembangkan berdasarkan teori kognitif kontruktivisme.

Pada metode pembelajaran kooperatif tipe Make and Match terlebih dahulu diajarkan belajar kelompok atau kerja kelompok. Hal ini bertujuan untuk mengenal dan memahami karakteristik satu sama lain dalam segi individu dan kelompok. Model pembelajaran tipe Make and Match dapat di terapkan untuk semuamata pelajaran dan tingkatan kelas. Model ini sangat disenangi peserta didik di karenakan guru dapat memancing kekreativitasan siswa sehingga pembelajaran bersifat aktif. Dalam model pembelajaran make a match terdapat hal yang dapat menarik siswa agar siswa lebih semangat dalam melakukan pembelajaran, karena model ini sangat menyenangkan siswa akan secara langsung melakukan pembelajaran dan bermain sehingga peserta didik tidak merasa jenuh, pembelajaran dilakukan dengan menyenangkan dan tidak monoton dengan menggunakan model pembelajaran tipe Make A Match.

Make A Match bertujuan untuk menumbuhkan sikap saling menghormati, menumbuhkan sikap tanggung jawab, meningkatkan percaya diri dalam menyelesaikan suatu masalah, (2) merupakan model pembelajaran yang menuntut anak didik aktif dalam pembelajaran, keterampilan keterampilan mulai dari tingkat awal maupun tingkat mahir yang dimiliki anak didik akan terlihat dalam pembelajaran ini, (3) 
lingkungan dalam pembelajaran Make A Match diusahakan demokratis, anak didik diberi kebebasan untuk mengutarakan pendapat (Djumiati, 2010: 35). Selain menggunakan model pembelajaran yang menarik diperlukan juga media pembelajaran yang juga menjadi faktor pendukung keberhasilan dalam menerapkan model pembelajaran, sehingga mampu meningkatkan gairah belajar dan meningkatkan kemampuan viual peserta didik jika media yang digunakan menarik atau variatif. Sehingga dalam penelitian ini penulis menggunakan bantuan media kartu bergambar (Hazilla, 2018).

Dengan menerapkan model tipe Make and Match dalam pembelajaran, penggunaan media untuk meningkatkan hasil belajar kognitif peserta didik juga sangat diperlukan. Pembelajaran yang menggunakan media yang sesuai akan memberikan manfaat yang sangat besar dalam proses pembelajaran. Media pembelajaran memiliki kontribusi yaitu menyampaikan pesan pembelajaran dapat lebih terarah, menarik dan interaktif. Dengan menerapkan media pembelajaran, waktu pelaksanaan pembelajaran dapat berlangsung kapanpun dan dimanapun di perlukan dalam pembelajaran. Sikap positif peserta didik terhadap materi pembelajaran serta proses pembelajaran dapat ditingkatkan, dan peran guru berubah ke arah yang lebih positif. Dalam penelitian yang di lakukan, peneliti memberikan alternatif media PANTERU (Papan Tempel Seru) yang dapat menarik peserta didik dalam proses pembelajaran.

Berdasarkan pembahasan dari latar belakang tersebut dapat disimpulkan bahwa model pembelajaran tipe Make and Match merupakan model pembelajaran yang inovatif. Dimana dapat digunakan pada proses pembelajaran TEMATIK tema 6 (cita-citaku) Sub tema 1 (aku dan cita-citaku) pembelajaran 2 sebagai pedoman dan tutorial dalam pembelajaran kelas IV SDN Pujut 01 Batang.

Berdasarkan penelitian dari latar belakang tersebut, peneliti memilih judul "keefektifan model pembelajaran Make and Match berbantu media Panteru ( Papan Tempel Seru) terhadap hasil belajar kognitif siswa pada pembelajaran tema 6 subtema 1 kelas IV SDN Pujut.

Kata "media" berasal dari bahasa Latin "medium" yang berarti "perantara" atau "pengantar". Lebih lanjut, media merupakan sarana penyalur pesan atau informasi belajar yang hendak disampaikan oleh sumber pesan kepada sasaran atau penerima pesan tersebut. Penggunaan media pengajaran dapat membantu pencapaian keberhasilan belajar. Ditegaskan oleh Danim bahwa hasil penelitian telah banyak membuktikan efektivitas penggunaan alat bantu atau media dalam proses belajar-mengajar di kelas, terutama dalam hal peningkatan prestasi siswa. Terbatasnya media yang dipergunakan dalam kelas diduga merupakan salah satu penyebab lemahnya mutu belajar siswa.1 Dengan demikian penggunaan media dalam pengajaran di kelas merupakan sebuah kebutuhan yang tidak dapat diabaikan. Hal ini dapat dipahami mengingat proses belajar yang dialami siswa tertumpu pada berbagai kegiatan menambah ilmu dan wawasan untuk bekal hidup di masa sekarang dan masa akan datang. Salah satu upaya yang harus ditempuh adalah bagaimana menciptakan situasi belajar yang memungkinkan terjadinya proses pengalaman belajar pada diri siswa dengan menggerakkan segala sumber belajar dan cara belajar yang efektif dan efisien.2 Dalam hal ini, media pengajaran merupakan salah satu pendukung yang efektif dalam membantu terjadinya proses belajar. Pada proses pembelajaran, media pengajaran merupakan wadah dan penyalur pesan dari sumber pesan, dalam hal ini guru, kepada penerima pesan, dalam hal ini siswa. Dalam batasan yang lebih luas, Yusufhadi Miarso memberikan batasan media pengajaran sebagai segala sesuatu yang dapat digunakan untuk merangsang pikiran, perasaan, perhatian, dan kemauan siswa sehingga mendorong terjadinya proses belajar pada diri siswa.3 Apabila dilihat dari manfaatnya Ely dalam Danim menyebutkan manfaat media dalam pengajaran adalah sebagai berikut: (a) Meningkatkan mutu pendidikan dengan cara meningkatkan kecepatan belajar (rate of learning), (b) Memberi kemungkinan pendidikan yang sifatnya lebih individual, (c) Memberi dasar pengajaran yang lebih ilmiah, (d) Pengajaran dapat dilakukan secara mantap, (e) Meningkatkan terwujudnya kedekatan belajar (immediacy learning), dan (f) Memberikan penyajian pendidikan lebih luas (Mahnun, 2012).

\section{Metode}

Metode yang digunakan dalam penelitian ini adalah menggunakan metode kuantitatif. Metode ini diartikan metode penelitian yang berdasarkan pada filsafat positivisme, digunakan untuk meneliti pada populasi tertentu, teknik pengambilan sampel pada umumnya dilakukan secara random, pengumpulan data menggunakan instrumen penelitian, analisis data bersifat kuantitatif atau statistik dengan tujuan untuk menguji hipotesis telah di tetapkan.

Desain penelitian yang digunakan dalam penelitian adalah One-Group Pretest-Posttest Design, yaitu sebelum diberikan perlakuan terhadap kelas yang dilakukan penelitian, terlebih dahulu di berikan soal Pretest dengan tujuan untuk mengetahui keadaan kelas sebelum diberikn perlakuan, maka dilakukan pengujian dengan cara memberikan soal Posttest untuk mengetahui keadaan kelas setelah di berikan perlakuan. 
Tabel 1. Rancangan Penlitian Desain One-Group (Pretest-Posttest Design (Sugiyono, $2016: 110-111$ ).

\begin{tabular}{llll}
\hline Kelas & Pretest & perlakuan & Posttest \\
Penelitian & $\longrightarrow \mathrm{O}_{1} \longrightarrow \mathrm{O}_{2}$ \\
\hline
\end{tabular}

Keterangan

$\mathrm{O}_{1}=$ Nilai Pretest (sebelum di beri perlakuan )

$\mathrm{O}_{2}=$ Nilai Posttest (setelah diberi perlakuan)

$\mathrm{X}=$ Perlakuan yang diberikan dengan pemberian model Make A Match berbantu media Panteru.

\section{Hasil dan Pembahasan}

Penelitian ini dilakukan di SDN Pujut 01 Batang tahun ajaran 2018/2019 yang dilaksanakan pada bulan Mei-Juni semester genap. Berdasarkan wawancara dengan guru kelas IV SDN Pujut 01 Batang yaitu ibu Rohkyati S.Pd.SD : bahwa pembelajaran di sekolah belum begitu moderen, dan guru masih jarang menggunakan model pembelajaran yang menarik minat siswa dalam belajar mengajar di dalam kelas, seperti menggunakan model ceramah saja. Yang menurut guru tersebut kurang variatif dengan yang ada pada buku BSE. Sehingga hasil dari peserta didik kurang memuaskan yaitu sebagian siswa masih di bawah KKM yaitu 70,00. Peneliti menerapkan model pembelajaran Make A Match dengan media yang menarik minat peserta didik, dengan harapan adanya perubahan terhadap hasil belajar siswa agar mengalami ketingkatan nilai dalam belajar dengan model dan media yang menarik. Model yang digunakan dalam penelitisn ini yaitu model pembelajaran Make A Match berbantu dengan media Panteru. Penelitian ini ditujukan untuk mengetahui keefektifan model Make A Match berbantu dengan media Panteru terhadap hasil belajar peserta didik kelas IV SDN Pujut 01 Batang.

Jenis penelitian ini adalah eksperimen menggunakan Pre Experimental Design yang digunakan dalam One-Group Pretest-Posttest Design. Populasi penelitian adalah seluruh peserta didik kelas IV SDN Pujut 01 Batang. Sampel yang digunakan adalah 16 peserta didik. Data dalam penelitian ini diperoleh melalui dokumentsi, tes dan wawancara tidak berstruktur. Penelitian awal peneliti melakukan uji instrumen untuk melakukan validitas, reliabilitas, daya pembeda dari tingkat kesukaran butir soal. Peneliti melakukan penelitian di SDN Pujut 01 Batang pada kelas IV. Setelah dilakukan analisis pengambilan butir soal, pneliti melakukan penelitian di SDN Pujut 01 Batang. Peneliti melakukan pretest untuk mengetahui kemampuan awal peserta didik kemudian peserta didik di berikan perlakuan dengan menerapkan model Make A Match berbantu media Panteru, kemudian peserta didik di berikan posttest untuk mengetahui kemampuan peserta didik setelah di berikan perlakuan.

Berdasarkan hasil uji tes awal atau pretest menunjukan bahwa sebagian peserta didik mendapatkan nilai belum mencapai KKM yaitu 70.00 yang telah ditentukan oleh sekolah. Pada hasil nilai pretest terdapat terdapat 11 dari 16 peserta didik dinyatakan tidak tuntas dan 5 dari 16 peserta didik dinyatakan lulus atau tuntas. Hasil Posttest menunjukkan bahwa nilai peserta didik seteah di berikan perlakuan menjadi lebih baik dengan rata-rata nilai yang memuaskan terdapat 2 dari 16 peserta didik dinyatakan tidak tuntas dan 14 dari 16 peserta didik dinyatakan tuntas dengan 88\%. Peserta didik yang tidak tuntas berarti memiliki nilai yang belum mencapai KKM yang ditentukan. Dengan nilai Posttest tersebut, menunjukkan bahwa model Make A Match berbantu media Panteru memberikan pengaruh yang baik terhadap hasil belaja kognitif siswa pada materi tema 6 subtema 1, perbedaan nilai menunjukkan adanya perbedaan anatara pembelajaran dengan diberikan perlakuan menerapkan model Make A Match berbantu media Panteru.

Berdasarkan hasil uji $t$ di peroleh $t_{\text {hitung }}>t_{\text {abel }}$ atau 8,063 $>1,753$ sehingga $\mathrm{H}_{0}$ ditolak dan $\mathrm{H}_{a}$ diterima, dari pengujian ketuntasan belajar individu nilai diatas KKM (70.00) sebanyak 14 peserta didik tuntas nilai KKM, dan dari pengujian ketuntasan belajar klasikal hasil belajar peserta didik secara keseluruhan mencapai presentase lebih dari 88\%. Dapat disimpulkan bahwa model pembelajaran Make A Match berbantu media Panteru efektif terhadap hasil belajar peserta didik pada materi Tema 6 Subtema 1 Pembelajara 1-3 di kelas IV SDN Pujut 01.

Hasil perhitungan diatas membuktukan bahwa penerpan model pembelajaran Make A match berbantu media Panteru efektif digunakan untuk meningkatkan hasil belajar kognitif siswa kelas IV SDN Pujut 01 Batang pada materi Tema 6 Subtema 1 Pembelajaran 1-3, dikarenakan peserta didik sangat aktif dalam mengikuti semua proses pembelajaran, peserta didik termotivasi, perhatian peserta didik lebih 
terpusatkan pada saat pembelajaran. Peserta didik mendapatkan tantangan tersendiri dalam pembelajran adanya umpan balik yang baik, dan peserta dapat menerima perbedaan yang ada.

Menurut Alfin ( (2016:294) dalam Ulfah Amaliya (2018) ) menyatakan bahwa pada dasarnya peserta didik adalah kemauan dan aspirasinya sendiri. Belajar hanya dapat terjadi apabila peserta didik aktif dalam mengalami sendiri. Guru memiliki peran sebagai pembimbing dan pengarah dalam pembelajaran. Menurut teori kognitif , belajar menunjukan adanya jiwa yang sangat aktif jiwa mengolah informasi yang kita terima tidak sekedar menyimpan informasi yang kita terima tidak sekedar menyimpan informasi tersebut. Pada saat penelitian peserta didik menunjukan keaktifannya dengan berani bertanya mengemukakan pendapat tentang hal-hak yang kurang dipahami dan mengerti, berani menjawab pertanyakan yang diberikan dan aktif saat saat melaksanakan petunjuk yang disampaikan.

Menurut Arifin (2016:294) dalam Ulfah Amaliya (2018) menyatakan bahwa motivasi adalah tenaga yang menggerakan dan mengarahkan aktivitas peserta didik. Motivasi dapat merupakan alat dan tujuan dalam penelitian pembelajaran. Sebagai alat, motivasi merupakan salah satu faktor penting seperti halnya intelegensi dan hasil belajar sebelumnya yang dapat menentukan keberhasilan peserta didik dalam belajar dalam bidang pengetahuan, nilai-nilai, dan ketrampilan. Sebagai tujuan, motivasi merupakan salah satu tujuan dalam mengajar. Dengan penerapan model Make A Match berbantu media Panteru dapat memotivasi peserta didik dalan belajar sehingga mudah memahami materi yang disampaikan dan hasil belajar yang diperoleh peserta didik meningkat.

Penerapan model Make A Matchberbantu media Panteru dalam penelitian sangan membantu memusatkan perhatian peserta didik saat pembelajaran ditunjukan dengan antusias peserta didik. Menurut Arifin (2016:294) menyatakan bahwa perhatian mempunyai peranan yang sangat penting dalam proses pembelajaran. Perhatian terhadap pelajaran akan timbul pada peserta didik akan timbul apabila bahan pelajaran sesuai dengan kebutuhan peserta didik.

Arifin (2016 :296) dalam Ulfah Amaliya (2018) menjelaskan bahwa dalam pembelajaran peserta didik menghadapi tujuan yang ingin di capai tapi selalu mendapat tantangan yaitu mempelajari bahan belajar, maka timbulah motif untuk menyelesaikan tantangan itu dengan mempelajari bahan belajar tersebut. Pada saat penelitian peneliti menerapkan model pembelajaran Make A Match berbantu media Panteru. Model dan media yang digunakan peneliti memiliki tantangan berupa peserta didik harus mencari pasangan dari kartu pertanyaan dan jawaban yang tepat sesuai aturan yang telah disepakati bersama. Dari tantangan tersebut peserta didik dapat menyelesaikan dengan baik.

Umpan balik yang diterima peneliti pada saat penelitian sangat baik. Hal tersebut ditunjukan dengan keaktifan peserta didik, adanya perhatian dan motivasi peserta didik mengikuti pembelajaran. Selain itu peserta didik juga mendapat hasil belajar yang memuaskan setelah peneliti menerapkan model pembelajaran Make A Match berbantu media Panteru dalam pembelajaran. Siswa lebih mengerti dan mudah memahami pembelajaran dengan baik dan dengan benar, siswa cepat memahami dengan model pembelajaran dan media yang digunakan seperti yang di jelaskan oleh Arifin 92016:296) dalam Ulfah Amaliya (2018) menjelaskan bahwa setiap peserta didik memiliki perbedan satu dengan yang lainnya. Perbdaan itu terdapat pada karakteristik psikis, kepribadian dan sifat-sifatnya. Perbedaan individual ini dapat berpengaruh pada cara dan hasil belajar peserta didik. Peserta didik menerima hasil belajar yang diperoleh karena pada saat pretest dan posttest berbeda. Peserta didik menerima hasil belajar yang diperoleh karena merupakan hasil kerja keras sendiri. Hasil belajar pada saat posttest mengalami peningkatan karena menerapkan model pembelajaran Make A Match dan media yang telah disiapkan oleh peneliti.

Berdasarkan uraian diatas, disimpulkan bahwa model Make A Match berbantu media Panteru dapat meningkatkan hasil belajar kognitif peserta didik dalam memahami materi yang diberikan guru dan dapat membantu peserta didik menemukan pertanyaan dan jawaban mengenai materi pada tema 6 Subtema 1 pembelajaran 1-3 pada kelas IV SDN Pujut 01 Batang.

\section{Simpulan dan Saran}

Berdasarkan hasil penelitian dan pemahasan dalam penelitian ini dapat disimpulkan bahwa penerapan model pembelajaran Make A Match berbantu dengan media Panteru (Papan Tempel Seru) efektif digunakan untuk meningkatkan hasil belajar kognitif peserta didik, pada materi Tema 6 Subtema 1 pembelajaran 1-3 di kelas IV SDN Pujut 01 Batang. Hal ini dibuktikan dengan hasil rata-rata nilai posttest analisis uji $t$ di peroleh $t_{\text {hitung }}>\mathrm{t}_{\text {tabel }}$ atau 8,063 $>1,753$ sehingga $\mathrm{H}_{0}$ di tolak dan Ha diterima, dari pengujian ketuntasan belajar individu nilai diatas KKM (70.00) sebanyak 14 peserta didik yang lulus KKM dengan nilai tuntas dari KKM, dan dari pengujian ketuntasan belajar klasikal hasil belajar peserta didik secara keseluruhan mencapai presentase $100 \%$. Meningkatnya hasil belajar peserta didik sebelum dan sesudah 
di beri perlakuan berupa pemberian model pembelajaran tipe Make A Match berbantu dengan media Panteru yang ditunjukan dengan hasil nilai rata-rata posttest yang meningkat.

Berdasarkan simpulan diatas maka saran yang bisa di paparkan dari penelitian ini yaitu :

1. Model Make A Match berbantu media Panteru efektif terhadap pembelajaran Tema 6 Subtema 1 pembelajaran ke 1-3 di kelas IV SDN Pujut 01, sehingga dapat dijadikan alternatif untuk pembelajaran. Caranya penerapan media Panteru yang berisi pertanyaan dan jawaban pada kartu soal dan jawaban, hal ini bertujuan untuk memancing daya ingat peserta didik tentang mater yang telah disampaikan melalui kartu media Panteru.

2. Pembelajaran Tema 6 Subtema 1 pembelajaran ke 1-3 dengan model pembelajaran Make A Match dapat dikolaborasikan dengan media Panteru agar peserta didik semangat, senang dan tidak bosan dalam melakukan kegiatan pembelajaran yang sedang berlangsung.

3. Pembelajaran dengan menggunakan model pembelajaran Make A Match berbantu dengan media Panteru dapat dijadikan motivasi dan inovasi pembelajaran yang aktif, inovatif kreatif, efektif dan menyenangkan bagi guru.

\section{Daftar Rujukan}

Anitah, Sri . 2010. Media Pembelajaran. Surakarta : Yuma Pustaka.

Drs.Daryanto, Dra Tutik Racmawati, M.Pd. 2015. Teori Belajar dan Proses Pembelajaran Yang Mendidik. Yogyakarta : Gava Media.

Emda, Amna. 2011. Pemanfaatan Media dalam Pembelajaran Biologi di Sekolah. Jurnal Ilmiah Didaktika Vol. XII No. 1, 149-162.

Hazilla, Dhestha. 2018. Penerapan Model Pembelajaran Kooperatif Tipe Make A Match Berbantuan Kartu Bergambar Untuk Meningkatkan Hasil Belajar Siswa . Jurnal Bidang Pendidikan Dasar (JBPD), Vol.2 No. 1A April 2018

Hamdani. 2011. Strategi Belajar Mengajar. Bandung : Pustaka Setia

Megawati, Priarti. 2012. Meretas Permasalahan Pendidikan Di Indonesia. Jurnal Formatif 2(3): 227-234 ISSN: 2088-351X

Muhammad Azza Ulinnuha, Suyitno, Singgih Adhi Prasetyo,Keefektifan Pembelajaran Tipe Make A Match Terhadap Hasil Belajar Mata Pelajaran IPA Kelas III SD Negeri Krompakan Kabupaten Kendal, , 2017 , : Jurnal Pendidikan. Volume 2. No 2 (671-6778).

Majid, Abdul. 2014. Penilaian Autentik Proses dan Hasil Belajar. Bandung: Remaja Rosdakarya.

Mahnun, Nunu. 2017. Media Pembelajaran (Kajian Terhadap Langkah-Langkah Pemilihan Media Dan Implementasinya Dalam Pembelajaran) . Jurnal Pemikiran Islam; Vol. 37, No. 1 Januari-Juni 2012

Ratumanan. 2015. Inovasi Pembelajaran. Yogyakarta: Ombak.

Ulfah Amaliya. 2018. " Keefektifan Penerapan Metode Make A Match Berbantu Media Panteru ( Papan Tempel Seru) Untuk Meningkatkan Hasil Belajar Kognitif Siswa Pada Materi IPA Pesawat Sederhana di Kelas V SDN Banyuputih 02 Batang" . Fakultas Ilmu Pendidikan. Universitas PGRI Semarang. Semarang.

Undang- undang Republik Indonesia Nomor 20 Tahun 2003 Tentang Sistem Pendidikan Nasional.

Sudjana, Nana. 2009. Penilaian Hasil Proses Belajar Mengajar. Bandung : PT Indeks.

Suprijono, Agus. 2009. Cooperative Learning. Yogyakarta : Pustaka Pelajar.

Sugiyono, 2015. Metode Penelitian Pendidikan. Bandung : Alfabeta.

Sagala, Syaiful. 2013. Etika dan Moralitas Pendidikan Peluang dan Tantangan Edisi Pertama. Jakarta: Kencana.

Sami, Ridwan Abdullah 2016, Penilaian Autentik, Jakarta, Bumi Aksara

Sanaky, Hujair AH. 2013. Media Pembelajaran Interaktif-Inovatif. Yogyakarta: Kaukaba Dipantara. 
Wandy. 2017. Metode Pembelajaran Make A Match Untuk Meningkatkan Hasil Belajar Bahasa Indonesia Siswa Sekolah Menengah Pertama . Jurnal Ilmu Pendidikan Sosial, sains, dan Humaniora Vol. 3 No. 1, Maret 2017

Wibowo , Krisno Prasetyo dan Marzuki. 2015, Penerapan Model Make A Match Berbantu Media Untuk Meningkatkan Motivasi Dan Hasil Belajar IPS. Harmoni Sosial : Jurnal Pendidikan IPS. Volume 2, No 2 9158-169)

Zubaidah, Enny , 2015. Pemanfaatan Media Pembelajaran untuk menciptakan Lingkungan Kelas SD. Jurnal Prima Edukasia, Volume 3, Nomor 1 ( 46-60). 